
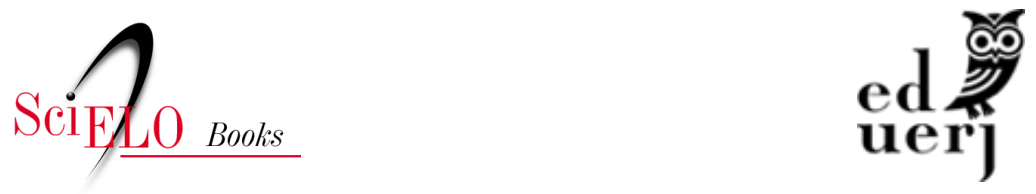

\title{
Sentidos e significados do natural
}

\author{
Maria Cláudia da Veiga Soares Carvalho
}

\section{SciELO Books / SciELO Livros / SciELO Libros}

CARVALHO, M. C. V. S. Sentidos e significados do natural. In: Bricolagem alimentar nos estilos naturais [online]. Rio de Janeiro: EDUERJ, 2013, pp. 105-129. ISBN: 978-65-88808-07-8. https://doi.org/10.7476/9786588808078.0008.

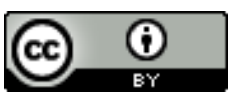

All the contents of this work, except where otherwise noted, is licensed under a Creative Commons Attribution 4.0 International license.

Todo o conteúdo deste trabalho, exceto quando houver ressalva, é publicado sob a licença Creative Commons Atribição 4.0.

Todo el contenido de esta obra, excepto donde se indique lo contrario, está bajo licencia de la licencia Creative Commons Reconocimento 4.0. 


\section{Sentidos e significados do natural ${ }^{1}$}

\section{A ressacralização da Natureza como Gaia}

Gaia é uma deusa que personifica a Terra, com sua grande potencialidade feminina, geradora de todas as coisas: aquela que dá e tira as coisas do homem. Uma deusa que dá nascimento ao homem e, depois de sua morte, recolhe-o e o guarda em seu seio. Uma divindade primordial que nasce do caos. O mito de Gaia representa as forças da Natureza, forças elementares que oferecem sustento ao homem e possibilitam a ordem do mundo, segundo a qual somos apenas uma espécie diferente no planeta.

Alguns autores discutem a atribuição de um sentido sagrado à Natureza numa perspectiva romântica. $\mathrm{Na}$ teoria sobre Gaia, Lovelock (1991) logo se intitula um romântico no papel de cientista autocentrado, autodidata, livre das prisōes subvencionistas das ciências; segundo ele, sua "única ajuda foi um dicionário". No início de seu livro, cita Rousseau com a imagem de que o homem é bom por natureza, e que seria a sociedade que o corrom-

1 No final do texto, estão listados alimentos e práticas culinárias com sentidos e significados detalhados. 
pe, quando descreve de modo apaixonado o interior da Inglaterra como um jardim paradisíaco, onde as orquídeas cresciam nas grotas - um paraíso terrestre. Repudia que a teoria de Gaia seja teológica, mas produz uma rica narrativa, quase bíblica, sobre sua súbita sensação de epifania ao ver Gaia pela primeira vez: "a mão invisível da vida", "a dádiva de ver a terra de longe" (p. 26). Além disso, escreveu a parábola do margaridal para explicar uma teoria sobre Gaia. O link de Gaia com o romantismo é a grandiosidade de sua narrativa mítica.

Segundo Campbell (2001), a ética romântica está articulada ao consumismo moderno na construção de um imaginário com cenas distantes do cotidiano, fantasiosas, capazes de inspirar grandeza, paixão e de facilitar a revolução industrial na economia moderna. De acordo com o autor, os românticos interpretavam a Natureza quer como aqueles atributos inatos que são mais espontâneos, não tocados pela reflexão ou pelo desígnio, livres do cativeiro da convenção social, quer como aquelas partes do universo que vêm a existir independentemente dos esforços e das intenções humanas. Assim, "em vez de 'mergulhar' o sobrenatural no natural, eles preferiram 'erguer' o natural até o status de sobrenatural” (p. 257).

O romantismo do estilo natural orienta um controle de emoções que não exatamente impede a expressão emotiva; ele a modula. Um habitus romântico motiva a expressão do sentimento humano em sua disposição para o sonho, para o ideal, para o individual, egocêntrico e subjetivo, na transição para certo realismo que denuncia vícios e males da sociedade, revelando suas fragilidades.

A Natureza passa de mera paisagem a uma essência sagrada em Gaia, numa concepção capaz de fundir o belo e o feio e de dar uma roupagem atraente à boemia, como na geração "sexo, drogas e rock'n' roll". Ela é a mais bela e pura expressão do estado de espírito do homem, se expressa na sensibilidade especialmente com relação a emoções como piedade, suavidade, amabilidade, 
particularmente para com as crianças e os animais, com um sentido de intuição.

O romantismo não poupa incômodos; empolgado pela idealização dos objetos, coloca em destaque a sensibilidade e a percepção aguçada. Para Campbell (2001), o prazer se sobressai no romantismo como um sentimento bom e belo, e a crueldade é sinônimo de insensibilidade. $\mathrm{O}$ individualismo é perverso porque insensível. Esse romantismo a que remete o autor transforma a Natureza boa e selvagem (ideia rousseauniana) em Natureza boa e sensível.

O mal-estar causado pela modernização, representado no combate ao artificial, ao tecnológico como maléfico, tornou a $\mathrm{Na}$ tureza "danificada", e sua restauração está possivelmente perdida para sempre:

[...] uma deterioração progressiva do meio ambiente planetário na segunda metade do século passado, produzida pelo desenvolvimento industrial apoiado em uma tecnologia invasiva e predatória da natureza, com os conhecidos efeitos da poluição atmosférica, pluvial e marítima, da erosão, do assoreamento, da desertificação e da depredação de sítios e nichos insubstituíveis da natureza, pondo-se em risco a diversidade biológica e a própria sobrevivência da humanidade no planeta (Luz, 2003, p. 50).

Lovelock apresenta aspectos de sustentabilidade do naturismo quando teoriza sobre Gaia como cientista que se permite fazer desabafos, deslocando-se para fora do campo científico tradicional, trocando a ideia de verdade pela de eficácia: "Pouco importa se a teoria de Gaia está certa ou errada, o fato é que ela já está proporcionando uma ideia nova e mais produtiva da Terra e dos outros planetas" (1991, p. 58). A reinvenção de uma condição sustentável para o planeta também é sentimental no relato de um vegano: "A crise vai quebrar o sistema... Sem autossustenta- 
bilidade, uma hora vai acabar. Tem que ter outra forma de ver o mundo. $\mathrm{O}$ mundo terá que ser reinventado, não vai haver muitas águas, muitas terras...”.

A concepção de Gaia está inteiramente ligada ao conceito de uma vida natural. Para Lovelock, a Terra é um sistema de várias pequenas comunidades de tecidos e micro-organismos, o que denomina de coligativo, em que propriedades como a temperatura e a pressão mantêm condições favoráveis à vida: um sistema autorregulador integrado. Embora essas pequenas comunidades pudessem viver isoladamente, como já viveram livres um dia, elas o fazem integradas porque a vida é social. Lovelock apresenta a pesquisa de Linn Margulis, que, segundo ele, estabeleceu um contexto básico para construção de Gaia.

Para essa bióloga, a organela que vive em nossas células, a mitocôndria, já viveu livre, fora delas, como um organismo autônomo. Em algum momento longínquo, essa organela, antes um minúsculo ser, integrou-se às células de outros seres numa relação simbiótica, de tal modo que uma não vive mais sem a outra em nosso corpo. Milhares de células de nosso organismo compartilham suas vidas com as mitocôndrias e, por meio dessa relação, conseguimos gerar muita energia em cada uma das células de nosso corpo como jamais faríamos sem elas, pois a mais produtiva via metabólica de produção de energia bioquímica - via aeróbica ou fosforilação oxidativa - ocorre no interior da mitocôndria.

A integração de microssistemas em nosso corpo é possível pela semelhança que eles têm com o meio interno de nossas células, em que hoje habitam as mitocôndrias e que se parecem com a composição dos oceanos no passado, onde possivelmente elas habitavam. Segundo a teoria de Lovelock, Gaia é um grande sistema que necessita da relação de variados microssistemas, o que mantém o equilíbrio do todo. As transformações ocorridas ao longo do tempo são parte de um processo de adaptação entre esses microssistemas, que, após se integrarem, passaram a representar 
um só sistema de vida. Gaia integra esses variados sistemas dinamicamente, numa mutação que é parte do jogo da vida e implica inclusões e exclusões.

Gaia não é uma carinhosa mãe tolerante com as transgressões, nem alguma frágil e delicada donzela ameaçada pela humanidade brutal. Ela é dura e severa, mantendo sempre o mundo muito agradável e quentinho para os que obedecem às suas regras, mas é implacável na eliminação dos transgressores (p. 199).

Certa vez, almoçando com um dos entrevistados, perguntei-lhe como Gaia, uma mulher tão sabida e senhora de si, podia ter sofrido tantos abusos e chegado ao ponto de degradação que chegara. Ele respondeu que Gaia tinha sua lógica, difícil de compreender, mas que, se pensássemos que ela havia perdido o controle, estaríamos subestimando-a. Ela, como autônoma, se renovará. O problema será o que fica e o que muda no mundo, na transformação que virá. Essa forma de entender a deterioração do planeta se associa com o mito, em que Gaia gera sozinha um filho, Urano, e com ele faz doze filhos, os poderosos Titãs. Mas, vingativa - porque Urano, com medo, recoloca os filhos em seu útero -, ela engendra um plano com o filho, Cronos, e castra o pai, o que representa a separação do Céu e da Terra. Urano é o planeta regente da Era de Aquários, elemento simbólico constituinte do mito, associado à intuição e às percepções vindas do coração.

O imaginário em torno de Gaia se reproduz no estilo natural por meio de preocupações ecológicas com o planeta em função do projeto de um mundo menos poluído e degradado, no qual as próximas gerações sejam capazes de suprir suas necessidades. Os naturistas têm um cuidado especial com a classificação do lixo e, por isso, estipulam uma escala de valores em que os resíduos inteiramente recicláveis são menos poluidores que os parcialmente recicláveis. Os químicos retidos na Natureza são os mais poluido- 
res, considerados venenos perigosos. O lixo chamado químico é o mais combatido e se constitui como o pior de todos; faz bricolagem com a ideia de entidade já discutida. Falar que uma comida está cheia de "química" é torná-la envenenada. Um dos panfletos dos restaurantes dizia: "Não jogue na rua! Guarde ou passe para alguém"; e outro, num estabelecimento vivo, informava: "Essa é a alimentação do futuro porque não deixa lixo; o lixo orgânico volta para a terra".

Os naturistas têm incorporada uma desconfiança em relação à ideia de descartabilidade que os predispõe, na prática, à reciclagem e à reutilização de materiais. $\mathrm{O}$ papel deve ser reciclado, economizado e até evitado, pois representa a extinção de árvores e florestas. Uma vegana comentou que não devíamos usar tanto papel para limpeza. Segundo ela, a melhor maneira de fazer higiene, inclusive a íntima, é com água: "É só uma questão de hábito; criei todos os meus filhos lavando-os com água, com o mínimo possível de papel higiênico, e eles estão fortes e saudáveis". Na feira da Glória, os clientes levam as próprias sacolas para as compras, e até mesmo os pequenos sacos plásticos que envolvem os alimentos são reutilizados. Numa manhã, conheci uma moça estrangeira, frequentadora da feira, que chegou à barraca de hortaliças com vários saquinhos transparentes para embalar sua compra; todos já tinham sido utilizados e estavam igualmente dobradinhos para serem novamente usados. Ela colocou cada uma das verduras compradas em saquinhos que, juntos, foram acomodados numa mesma sacola, também trazida de casa, meio velhinha, de pano. Essa atitude não surpreendeu as pessoas, era costume na feira. Repreensível seria se não fosse assim.

A reutilização de materiais é um princípio que orienta a ação. Um entrevistado que participava dessa feira havia seis anos reutilizava as caixas de papelão dos vinhos, rearranjadas de modo criativo, com o fundo protegido por adesivo transparente, para dar praticidade à rápida montagem e remontagem da barraca. 
Não havia sentido algum em descartar esse material para substituí-lo por um novo. Ainda que se aproveitem também sacolas plásticas descartáveis nesse espaço, o uso de sacolas de pano ou de plástico reutilizáveis (mais resistentes) faz parte de um costume "politicamente correto" que ganha prestígio nas relações sociais e no projeto de diminuir a poluição do planeta.

Um expositor de artesanato utilizava folhas de coqueiro, que seriam usualmente jogadas no lixo, para fabricar cestos e artefatos de decoração. Seu fazer era tão importante quanto o produto final, pois o valor estava no processo de uso do descartável. Algumas pessoas paravam em frente a ele e tentavam entender como conseguia aquela transformação; isso fazia todo o encanto - e a diferença. Perguntei como tinha aprendido o ofício, e ele disse que fora graças a um amigo que também vendia esses artefatos. Tal resposta parecia já ter sido dada diversas vezes, dispensava novas perguntas e dava conta inteiramente de nossa curiosidade. Outro expositor fabricava instrumentos musicais de percussão, como pandeiros e chocalhos (maraca, ganzá, caxixi, xique-xique), com garrafas PET.

O descarte de materiais não é visto com bons olhos também na culinária. O uso integral dos alimentos é reforçado nas preparações que evitam retirar as cascas de frutas ou partes que, embora consideradas comestíveis, não têm sido comumente utilizadas. Assim, usam-se as folhas da beterraba, da cenoura, da couve-flor, não se desprezam as do brócolis, nem os talos. Na feira da Glória, esses vegetais são vendidos inteiros, com as folhas. Os cereais são consumidos integralmente, como obra da Natureza. Por que separar o que Deus fez junto? A Natureza é o modelo a ser seguido; a mãe Terra sabe tudo que é primordial na vida do planeta e do homem. Quando perguntei sobre o uso dos farelos e das misturas de fibras, um entrevistado disse que isso era uma bobagem: "Tem que comer o alimento integral mesmo". 
Terra é a cor que predomina na culinária natural. $\mathrm{O}$ açúcar mascavo substitui o branco, o arroz integral substitui o branco, os ovos marrons são melhores que os brancos e o gersal, mistura de gergelim e sal, é colocado em cima das refeições e dá uma cor "boa" aos pratos. O shoyu faz o molho da salada mais escuro. $\mathrm{O}$ guaraná natural é a bebida tradicional nesse estilo. Nada disso é estranho para o naturista, embora diversas vezes seja para os outros, sem muita familiaridade com essa aparência. Numa ocasião, uma vegana levou o namorado novo a um restaurante desse tipo, e ele se recusou a comer, ressentindo-se da aparência quando a refeição chegou. Alguns comensais expressam disposições previamente incorporadas, facilitadoras para uma iniciação; outros ainda precisariam reconhecê-las, aderindo ao gosto pelo alimento natural na experiência, com o tempo.

A culinária do vivo se destaca dessa coloração terra porque está voltada para o sol. Os alimentos são bastante variados nas cores, ornamentados com flores e frutas diversas. A área do Terrapia, como já está no nome, é na terra, toda aberta ao tempo, sem cobertura, embaixo de árvores. Suas instalações são varandas amplas e a cozinha tem uma janela grande, voltada para as árvores. Também no núcleo da PUC-Rio a professora do Departamento de Artes, Ana Branco, ministra o curso de alimentação viva em área livre, numa tenda no campus. Ensina a fazer da alimentação uma arte com cores vivas e variadas, em que cada textura, cada tom são oriundos de uma mistura de frutas e sementes. Uma das entrevistadas, formada em Artes na mesma universidade, investiu também no lado artístico dos pratos em seu restaurante; segundo ela, eles ficam meio gourmet.

O suco mais típico desse estilo é o da luz do sol; um suco muito utilizado como repositor de energia vital, feito com a grama do trigo e/ou outras verduras, maçã e legumes, todos batidos no liquidificador e coados no pano. A clorofila é a substância mágica do suco da luz; com seu verde forte, está associada ao vermelho do 
sangue: a clorofila está na seiva das plantas, assim como o sangue em nossas veias, e o magnésio, que dá a ela a coloração verde, tem posição molecular similar à do ferro, responsável pela coloração vermelha. A alimentação do vivo merecia um estudo à parte por sua riqueza de elementos simbólicos.

A variedade reduzida na oferta do prato do dia não constitui um problema. $\mathrm{O}$ cuidado maior está na confiança em relação à comida. Nos restaurantes naturais, não há muitas opções; geralmente, eles seguem um ou mais pratos do dia e tentam oferecer os vegetais que estão na safra, de acordo com as leis da Natureza. A escolha do comensal segue a escolha do restaurante, que costuma apresentar o cardápio num quadro único, exposto para que todos o vejam e conversem sobre ele. Os proprietários ou funcionários apresentam as opções diretamente, em conversa informal com os clientes. Às vezes, o que se escolhe é somente se a porção vai ser meia ou inteira, confiando ao local a escolha do prato do dia. Percebemos uma familiaridade e um cuidar nessas conversas informais para apresentar o cardápio. Em várias oportunidades, foi possível acompanhar as explicações sobre os alimentos oferecidos no dia. Nessa conversa, são relembradas características dos comensais, atualizadas algumas questôes, reconhecendo-se gostos ou dificuldades alimentares com carinho. A credibilidade do local leva à intimidade e à familiaridade, pois os comensais desenvolvem o costume de comer nos mesmos lugares. Os proprietários transmitem aos funcionários os aspectos importantes sobre a alimentação servida, de modo que possam dar explicações e atender aos clientes, além de preparar as refeições. Num dos estabelecimentos, era a cozinheira quem pegava os pedidos, pelo próprio celular, e fazia as reservas, como se fosse proprietária também.

O sentido de ecologia no estilo natural engendra um gosto por alimentos e produtos regionais e ameaçados de extinção, como acontece com o que vem da Amazônia, as castanhas e nozes do tipo pecan, algumas frutas típicas, como açaí e guaraná, além 
do couro vegetal e de cosméticos. Valoriza a substituição de artefatos de couro de origem animal pelos de origem vegetal. O couro vegetal é feito com látex, produto típico das seringueiras da região amazônica. Nesse mesmo sentido, o de manter a diversidade de espécies, são também valorizados os alimentos regionais, como certas verduras (taioba, caruru e couve rábano) e plantas terapêuticas que nascem espontaneamente. Uma entrevistada, ao ressaltar as qualidades de um amigo quando foram acampar juntos, disse que ele sabia usar os recursos que a Natureza oferecia como jamais visto; que se virava muito bem com quase nada. Segundo ele, as plantas medicinais estavam espalhadas na mata - era só procurar. A Natureza é soberana, tem tudo de que precisamos.

Os ambientes dos restaurantes são construídos com rusticidade, valorizando uma iluminação suave, e aproveitam a luz do sol, sem o brilho de luzes fortes. Alguns locais me remetiam à imagem de um útero materno, como no mito de Gaia. Era raro encontrar móveis de metais; a maioria do mobiliário era de madeira, alguns itens com pedaços de tronco pouco trabalhados. Num dos restaurantes, havia uma varanda voltada para um jardim que era um orgulho para o proprietário, o que demonstrava a importância de plantas e pássaros em detrimento da otimização do espaço, que poderia ser maior se não fosse o jardim, para colocação de mesas. As mesas grandes promovem aproximações e novos encontros entre os comensais. Segundo relato de um vegetariano, num dos estabelecimentos que ele montou, tudo começou com um mesão num local que ainda nem era um restaurante propriamente dito: "Posso ir para qualquer lugar que vou botar uma comidinha; é minha missão". Outro restaurante tinha uma mesa bem grande, maior que as outras; ficava na varanda. Era a mais concorrida. Nela, as pessoas que sentavam próximas conversavam sem constrangimento.

A sonoridade desses espaços também tenta reproduzir um ambiente silencioso, sem música ambiente, com clima de mon- 
tanha. O som oriundo da conversação dos usuários, que fica ao longe, parece muito mais baixo do que o ruído que poderíamos observar, por exemplo, numa churrascaria. $\mathrm{O}$ ritmo mais lento para fazer a refeição também dá uma impressão de que os talheres batem menos uns nos outros e nos pratos. Numa visita, pude ouvir um som de celular que era o canto de passarinhos.

$\mathrm{O}$ investimento na agricultura orgânica e familiar segue esse sentido, o de uma produção favorável à vida no planeta. A modernidade trouxe um veneno para as plantas crescerem mais rápido, o que representa um desrespeito ao processo natural de crescimento, sagrado. Os agrotóxicos e aditivos alimentares são considerados lixo químico da pior espécie e motivaram um sentimento de revolta contra a produção em larga escala e o fast food. Natural é o autêntico, o leite puro da vaca, um alimento de um animal que teve liberdade para andar solto na Natureza, sem confinamento, ou os ovos de galinha caipira, uma galinha feliz. Lixo são os hormônios, agrotóxicos e alimentos transgênicos, que vão contra a ordem natural de Gaia.

\section{A impureza da carne}

O significado de "sujo" segue uma ordenação de higiene que foi se alterando com o movimento higienista e absorvendo regras mais rigorosas, numa transformação que se deu entre o final do século XIX e o início do XX. Segundo Douglas, as reações à sujeira e à impureza são também reaçôes a "anormalidades", a coisas inoportunas, e fazem parte de um processo de organização social. As concepções de pureza, antes de significarem normas institucionais, seguem uma relação construída socialmente entre a ordem e a desordem, ser e não ser, forma e não forma, vida e morte.

Onde há sujeira há sistema. Sujeira é um subproduto de uma ordenaçãao e classificação sistemática de coisas, na medida em que 
a ordem implique rejeitar elementos inapropriados. Essa ideia de sujeira leva-nos diretamente ao campo do simbolismo e promete uma ligação com sistemas mais obviamente simbólicos de pureza (1976, p. 50).

A Natureza, considerada sagrada, é um símbolo intocável de pureza para os naturistas. A ideia de poluição não está ligada aos mesmos elementos destacados nas políticas higienistas; remete às causas ecológicas, a um perigo para a vida do planeta. As novas tecnologias de alimentos têm um significado de poluição, pois representam modos de desorganização da Natureza, materializados nos aditivos, considerados venenos alimentares. $\mathrm{O}$ significado de pureza no alimento natural ou vivo está em conjunção com a ordem da Natureza, e o processo industrial está relacionado a seu oposto, ao que não é natural, o artificial, capaz de modificar os significados e os gostos dos alimentos. O sal do Himalaia é valorizado como um alimento puro porque é muito pouco manipulado, não é industrializado. A industrialização é nefasta, envolve interesses lucrativos, que, em graus diferentes, tornam os alimentos "sujos". As exigências de pureza no estilo natural não seguem os preceitos da vigilância sanitária, pois os aditivos alimentares são considerados venenos muito mais perigosos do que os micro-organismos patogênicos. Os piores lixos não os orgânicos, mas os químicos, feitos pelo homem, capazes de devastar e poluir o ambiente mais que qualquer outro agente.

Não notamos o uso de máscaras nem de luvas nos funcionários dos restaurantes, e não parece que isso seja acidental, mas, ao contrário, uma forma de conferir valor à preparação. Certa vez, um dos proprietários de um restaurante, que também entendia de plantas medicinais, trouxe à minha mesa um grão em germinação para mostrar detalhes, sem considerar sujeira a terra que o envolvia; ele estava trazendo um pouco do que era para ele símbolo de pureza e vida. $\mathrm{O}$ mesmo aconteceu com uma batata do tipo 
yacon, que me foi apresentada quase como um troféu, fresca porque recém-saída da horta ainda com um pouco de terra. Nos vídeos que ensinam sobre alimentação viva, a filtragem dos extratos é feita através de pano, nunca de peneiras plásticas; uma forma de coar que é necessariamente feita com as mãos, seja numa cozinha, seja sob uma árvore. Os alimentos naturais são considerados limpos quando livres de agrotóxicos.

O natural utiliza as cascas de vegetais que, na alimentação fast food, seriam desprezadas como lixo. Segundo Santos, "o conceito de naturalidade está vinculado à noção de pureza e impureza, ao estado mais puro do alimento. [...] ligada a uma noção de nostalgia do espaço social" (2008, p. 163), em que, "no estado original de inocência, éramos vegetarianos e alimentávamo-nos somente de ervas verdes" (Singer, 2004, p. 211). Skrabanec (1994) fala de uma ideia de pureza - defendida pelos higienistas do século XVII - ligada ao corpo, quando um puritanismo corporal se sobrepunha a uma liberdade corporal associada aos prazeres mundanos na Idade Média. Numa concepção puritana, a comida podia dar prazer quando era necessária, quando era para matar a fome, baseada no ascetismo e na operosidade, o que influenciou o movimento higienista da contemporaneidade. Segundo Serres, "nenhuma cultura atingiu o grau de ascetismo como o que hoje impõe a chamada civilização de consumo" (2001, p. 237). Os rituais e as regras higiênico-sanitários da alimentação moderna muitas vezes causam estranheza aos adeptos do estilo natural.

Rodrigues ressalta que as regras alimentares, incluindo gostos e desgostos, residem ordenadas no âmago de cada ser e que, dessa forma, inconscientes, podem nos transtornar violentamente. Com um olhar estranhador, narra uma passagem:

Um povo do Hemisfério Norte costuma ingerir pela manhã, num estranho ritual, uma secreção de uma glândula de determinado mamífero, ao qual se misturava um líquido de uma cor 
terrivelmente negra; figurava-se ainda, nessa tétrica cerimônia, uma gosma que determinados insetos vomitavam, células reprodutoras de aves e determinadas pastas gordurosas (1979, p. 68).

Igualmente estranha - na verdade, inconcebível - seria uma prática indígena em que a mulher mais velha da tribo mastiga uma comida e depois a devolve para o grupo todo se alimentar. Comer o que outro já colocou na boca misturado com saliva não nos é familiar, é sujo, embora não sejam sujos os beijos ardorosos de um casal apaixonado, o que talvez seja impensável em algumas aldeias. São organizações do puro e do impuro que estão incorporadas em nós sem nos darmos conta.

Ossipow (1989) observou que as preocupaçóes espirituais se associam a um desejo de fusão/retorno do homem com a Natureza e o Cosmos num movimento de elevação. Os movimentos espiritualistas higienistas motivaram a construção de sanatórios como o Battle Creek, do Dr. Kellogs, membro do movimento reformatório da Igreja Adventista do Sétimo Dia nos Estados Unidos, onde se divulgavam métodos de purificação das impurezas humanas, como o consumo de carne. Muitas dessas práticas perduram até hoje nos spas modernos, que, com adaptações, investem em tratamentos variados de limpeza e alimentação à base de vegetais. A concepção de "limpar o sangue" significa uma desintoxicação, tem um sentido de purificação, de jogar fora o mal por meio das secreções e excreções do corpo: "Antes de comer, tem que eliminar, até suar... Ir ao banheiro mais de uma vez ao dia”.

As misturas culinárias fazem parte de um conjunto de regras organizadas em torno de um padrão de pureza e controladas socialmente. Segundo Douglas (1976), os modos e os ingredientes devem seguir esse padrão; caso contrário, muitas vezes modos híbridos e outras confusões são abominados. As normas que organizam os significados garantem uma sensação de limpeza, e o caos pode nos dar uma sensação de sujeira. Por exemplo: o feijão deve 
ser colocado sobre o arroz (ou sob em alguns casos), minutos antes da refeição, evitando que se misturem demais; se vem o arroz muito misturado e mexido com o feijão, o prato não é valorizado, salvo seja um prato típico, como o baião de dois, cuja mistura funciona como uma preparação culinária organizada - um risoto. Ficaria ainda pior a aparência do arroz com feijão se a mistura ficasse muito líquida; isso daria uma impressão de resto de comida.

Um prato fora do padrão, desarrumado, que já foi mexido, ou cujo alimento foi devolvido da boca de outra pessoa é considerado sujo. A aparência deve ser a de um alimento que acabou de ser colocado no prato, não se misturando muito, e diretamente posto ali.

O mito de Gaia reforça a ideia de organização de diversos microcosmos articulados com uma totalidade. O Núcleo Ecológico de Cultura e Trabalho Alternativo Rural (Néctar), que começou com a iniciativa de seu proprietário de sair de uma área urbanizada na Taquara para um sítio no alto de uma floresta, mostra essa diversidade, característica do estilo natural. $\mathrm{Na}$ base de uma floresta bastante arborizada, na Estrada dos Bandeirantes, ele armou uma tenda onde vendia os artigos "alternativos" que produzia em seu sítio, como leite de cabra, queijo, mel, própolis e hortaliças. Em seguida, passou a fazer luaus e associar shows de rock aos produtos naturais. Hoje, o núcleo possui um restaurante e uma padaria vegetarianos, com alimentos orgânicos, um estúdio de música, uma loja de CDs raros, um brechó e um antiquário. Logo na entrada, podemos ler um cartaz na varandinha do restaurante anunciando ecoturismo, passeios, eventos e serviços de personal trainer. O Néctar vende uma diversidade de produtos naturais, mas nos enganaríamos se interpretássemos essa variedade como algo desordenado; há uma ordenação, que segue um estilo ou, como diria Douglas, schemas, que equivalem a habitus: 
É geralmente aceito que todas as nossas impressões são esquematicamente determinadas desde o início. Como observadores, selecionamos, de todos os estímulos que caem em nossos sentidos, somente aqueles que nos interessam, e nossos interesses são governados por uma tendência a padronizar, chamada algumas vezes de schema (ver Bartlett, 1932). Num caos de impressóes movediças, cada um de nós constrói um mundo estável no qual os objetos têm formas reconhecíveis, são localizados a fundo, e têm permanência. Percebendo, estamos construindo, tomando certas pistas e deixando outras. As pistas mais aceitáveis são aquelas que se ajustam mais facilmente ao padrão que está sendo construído (p. 51).

O desgosto pela carne representa a condenação do caos do mundo moderno, fora da ordem do mundo natural. Segundo Douglas, é a reação que condena qualquer objeto ou ideia capaz de confundir ou contradizer classificações ideais. No estilo natural, não deveríamos comer carne alguma, mas, se comemos, temos de garantir os direitos básicos aos animais abatidos; caso contrário, passamos de comensais a uma espécie de assassinos, que promovem uma "carnificina" animal. Nesse sentido, a comida dos veganos é mais pura, pois eles não ingerem alimentos animais de espécie alguma e não se sentem bem nem mesmo comendo perto de uma pessoa que esteja se alimentando de carne.

Ao longo dos anos, o vegetarianismo tem se distinguido socialmente e se legitimado como um julgador das práticas alimentares. Segundo Skrabanek, ele se tornou moda no século XVII, quando foi largamente difundida a ideia de sangue como um alimento que continha veneno, algo que devia ser evitado, o que promoveu uma resistência ao consumo de carnes, "cadáveres de animais" (1994, p. 171). Em 1847, foi formada a 1' Sociedade Vegetariana Inglesa por um grupo influente que condenava a violência do abate de animais. Esse foi um fenômeno tipicamente 
urbano e burguês, marcado por um distanciamento do mundo campesino, concentrado em grandes centros, onde habitam os animais mais humanizados, amigos do homem.

$\mathrm{O}$ vegan tensiona o abate de animais, fazendo uma analogia dessa prática com a violência que o homem sofre. Aceita a morte dentro das regras que considera natural. Num restaurante, havia um cartaz na porta dizendo: "Os animais são nossos amigos, não comida". Numa conversa informal, um entrevistado exclamou: "O alimento prova que Deus existe; aí o cara vai e corta o animal! Não come peixe, cara! O peixe morre por asfixia".

O desgosto pela carne é atribuído ao sofrimento pela morte do animal. Disse uma entrevistada:

Desde criança, não gostava de matança na fazenda; ficava horas olhando para a vaca, o pintinho. Era como se o animal fizesse parte da família. A questão de matar o bicho... O sangue é agressivo... Sinto como se estivesse me alimentando da morte do bicho, que é diferente da morte da planta.

Essa entrevistada contou ainda uma história de dois veterinários que foram tratar de um gado doente: um queria dar uma injeção com um remédio que poderia provocar problemas para quem comesse aquela carne, mas que evitaria o adoecimento do animal; o outro tentava isolar o gado e evitar a contaminação. Foi, no entanto, vencido por causa de interesses lucrativos. Nas palavras da entrevistada, a criação de gado é "um mundo do dinheiro".

A memória incorporada na vida desde a infância influencia a decisão por um estilo de alimentação. Queira ou não, o habitus incorporado gesta planos e projetos. Os veganos buscam livros e informaçóes sobre o vegetarianismo, numa tendência racional para a argumentação. Ser vegetariano é também saber argumentar, estar preparado para a pergunta: por que você não come carne? É preciso ainda ir além, estudar os alimentos; caso contrário, 
as pessoas podem entrar num vegetarianismo ruim. Os entrevistados vegetarianos sempre me traziam livros e encartes de jornal; em geral, dão cursos sobre o assunto, têm sites e vídeos ${ }^{2}$ explicativos. No decorrer da pesquisa, pude acompanhar dois congressos sobre o tema.

A articulação com o conhecimento científico é constituinte e está ligada a um impulso que pude observar nas entrevistas. Muitas vezes, foi preciso desviar do assunto sobre as vantagens nutricionais dos vegetais para ir adiante, sem ficar dando voltas no mesmo tema. As explicações bioquímicas eram muito atraentes e operavam como conhecimento científico legitimador do saber vegano, numa concepção de pureza que se liga a um projeto de se livrar do que o mundo moderno tem de sujo, um ideal de liberdade que envolve uma ordem natural com a construção de uma alternativa ao modelo convencional.

\section{Contracultura e liberdade}

$\mathrm{O}$ ativismo do habitus vegano nos fez refletir sobre uma concepção de liberdade. Uma concepção com herança de Rousseau, investida do romantismo nos termos de Campbell, motivador do devaneio e do consumo. Nesse sentido, o que se defende é que todos os homens nascem livres, e a liberdade faz parte de uma ordem social em prol da vida. $\mathrm{O}$ movimento social urbano denominado contracultura incorpora esse ativismo em busca de liberdade de ação e de uma alternativa ao caminho convencional, determinado pelo sistema capitalista. Ele foi desencadeado nos anos 1960 e prolongado durante os 1970 nos Estados Unidos e no continente europeu; segundo Luz (2003), atingiu grandes centros urbanos como o nosso, com a importação de modelos diferentes

2 Dois longa-metragens, Os terráqueos e $A$ carne é fraca, além de uma diversidade de curtas no Youtube. 
de sistemas terapêuticos, numa atitude de rejeição cultural ao modelo estabelecido. Assim como as novas terapêuticas, as práticas de alimentação natural se espalharam ocupando um espaço legitimado de resistência a um padrão fast food. De acordo com um entrevistado, a macrobiótica, junto a outras iniciativas, foi uma alternativa à ditadura, contra o consumismo e o capitalismo. As práticas alternativas tomaram um espaço do cuidar deixado pelo Estado, no recuo do Estado do bem-estar social para um Estado mínimo.

Simultaneamente à mudança da Era de Peixes para a de Aquários, deu-se início a lutas como a pelos direitos das mulheres, dos homossexuais e dos oprimidos, lutas relacionadas à construção de um mundo melhor, que prenunciavam um século XXI conturbado. No Zodíaco, Aquários é um signo de água, que envolve aspectos aéreos, científicos e intelectuais do ser humano; é regido pelo planeta Urano e pela intuição. A Era de Aquários representou um clima rico e efervescente, de mudanças profundas na classe média norte-americana. Depois do fim da Guerra Fria, jovens passaram a se recusar a ir para a Guerra do Vietnã, veio a aventura espacial, emergiu o rock'n' roll - associado a uma revolução sexual em busca do amor livre -, ganhou relevo uma nova forma de reagir às normas, com os hippies e a luta pelos direitos civis. Brotavam contestaçóes a tudo que era convencional; o "alternativo" se transformou em objeto de consumo por toda a Europa. Segundo Ossipow (1989), o mundo inteiro tinha a ilusão de o alternativo constituir uma nova ética e estética para a vida.

$\mathrm{Na}$ classe média carioca, em 12 de janeiro de 1979, uma carta de leitor publicada no Jornal do Brasil deu início a um movimento pela alimentação natural. Tudo começou com um texto inocente, de título "Comida sem veneno", que fazia uma chamada para um sistema cooperativo de distribuição de alimentos naturais: 
Os preços estão altos e a comida, morta ou contaminada. Como não parece mesmo haver qualquer solução oficial à vista, só resta nos organizarmos para produzir, distribuir e consumir alimentos frescos, puros e baratos. Esta carta é uma semente. A proposta é criar uma espécie de cooperativa que distribua para quem se interesse hortaliças (para começar) produzidas sem inseticidas nem outras químicas por quem tenha fazenda, sítio ou mesmo terreno grande em casa e queira aumentar ou diversificar sua renda, divertir-se e aprender plantando conforme a Natureza e contribuir para a melhora da alimentação dos sacrificados cariocas.

Um sonho coletivo por uma alimentação natural foi materializado na criação de uma cooperativa, a Coonatura, que foi se formando com um espírito de cooperação e fraternidade, a partir de conversas entre amigos, numa disposição para a ecologia, a macrobiótica, espiritualidades orientais; enfim, para práticas alternativas a uma vida que se revelou insuficiente para o sonho de um mundo melhor. Segundo participantes, a proposta era "plantar o trigo e fazer o próprio pão", transformando em prática um "discurso vazio" que criticava o consumismo e criando recursos e instrumentos para fortalecer um corpo que não queria se sujeitar facilmente ao mundo capitalista. $\mathrm{O}$ estilo natural de alimentação representou um instrumento para uma mudança de atitude que não implicava profundas transformações socioeconômicas, mas estratégias cotidianas de enfrentamento aos problemas globais. A alimentação macrobiótica era uma mudança estratégica em prol de uma vida melhor. Como disse um entrevistado, ela "é uma via para a felicidade e não para fazer cocô todo dia; é instrumental para uma mudança”.

Hoje, o naturismo não está ligado à alimentação macrobiótica, como no começo do movimento. Segundo uma entrevistada, 
a dieta macrobiótica consistia em ficar com $50 \%$ de arroz integral e depois ir complementando com alimentos secundários, não necessariamente só vegetais. Para a desintoxicação, eram necessários dez dias só com arroz integral sem temperos. $\mathrm{O}$ arroz integral era considerado o alimento mais equilibrado, yin e yang, o que purifica o sangue. Ser macrô era ser diferente do que é hoje.

Embora tenha seguido esse estilo por um tempo, a entrevistada criticou o caráter pouco saboroso da macrobiótica, que "não liga muito para o sensorial, para o prazer". Hoje, em sua alimentação, ela investe em sabores variados e na beleza dos pratos coloridos.

O estilo natural tem uma disposição para ressignificação e está atrelado a um sentimento de proibido proibir, de contestação ao convencional. $\mathrm{Na}$ busca por um mundo natural, foram sendo ressignificadas filosofias orientais, em contraposição às ocidentais, convencionais do mundo moderno. Às imagens do Oriente, foram atribuídos símbolos do bem viver. Para Montanari (2003), o encanto do Oriente é histórico, desde os significados de ostentação e distinção social em torno das especiarias, que alimentaram sonhos de abundância e felicidade com imagens de homens muitas vezes centenários, árvores sempre verdes e um espírito fênix que povoam as terras de lá, do outro mundo, o Paraíso terrestre.

O trabalho de Nogueira e Camargo aprofundou a questão da orientalização do Ocidente. Segundo eles, a imaginação do Oriente se torna central na construção de uma nova ordem global, com uma representatividade construída do ponto de vista do Ocidente ou, mais precisamente, do que o Ocidente denomina ocidental:

O Oriente é visto, por um lado, como uma civilização de rica tradição cultural, símbolo de sublimidade espiritual, força inspiradora e fonte de sabedoria; por outro, como uma região sombria de impenetrável mistério, irracional, não científica, portadora de um exotismo sinistro e ameaçador. De fato, o Oriente é 
um lugar que nos convida a voos imaginativos e exageros de toda espécie (2007, p. 2).

A bricolagem e o sincretismo foram estratégicos na construção de novas espiritualidades orientais, no estilo naturista. Nas palavras de um entrevistado, "religião eu tô tendo que criar uma pra mim; devemos pensar livremente e não seguir um modelo imposto, enfiaram [doutrinas] no meu... sem eu dar por conta. Acredito no respeito mútuo, fraternidade, amor ao próximo, me sinto como um invólucro de uma salsicha”. Jiddu Krishnamurti foi citado como aquele mestre verdadeiro que "não permitiu que lhe outorgassem o título de messias". Uma imagem de Ramatis ${ }^{3}$ se misturava com um quadro da Santa Ceia em cima da entrada de sua cozinha. Outra entrevistada, praticante do budismo, contou que essa foi uma forma de se rebelar contra a religião dos pais, em que ela não podia ouvir música, ir a baile etc.; foi uma atitude contestatória diante da inflexibilidade de dogmas religiosos.

Os naturistas se referiam a Deus como energia cósmica, um Deus que se confunde com a Natureza. Assim, o amor livre é natural, como a maconha e o rock'n' roll. A maconha não é algo recomendado, mas é considerada por muitos menos droga que o cigarro industrializado - é capaz de aumentar a percepção do mundo e da natureza do homem, "faz transparecer a alegria desse estado livre”. As bebidas alcoólicas, mesmo lícitas, são contraindicadas em diversos restaurantes; "é uma monstruosidade falar que vinho é bom para a saúde”. O vinho natural que pude experimentar é zero ou quase zero de teor alcoólico.

Um núcleo espiritualista citado nas entrevistas foi o de Trigueirinho, estabelecido numa fazenda em Minas Gerais, que so-

3 Ramatís, Rama-tys ou Swami Sri Rama-tys é o nome atribuído por médiuns de diversos países a um espírito que seria o autor/inspirador de dezenas de obras escritas. 
brevive com trabalhos voluntários e doações. Sua espiritualidade foi levada a outro núcleo por uma adepta que construiu um sítio em Teresópolis, o Crescendo, onde habitava a esposa de um entrevistado com sua filha, menor de nove anos. Estavam todos em busca de uma educação melhor do que a das escolas convencionais, as quais não estavam dando certo. Quando perguntei sobre entrar na faculdade, a entrevistada disse que o diploma era só um papel, sem sentido, não valia nada. Outros filhos dela abandonaram a escola convencional e depois, quando quiseram, foram para a faculdade. O Crescendo segue princípios da antroposofia e da filosofia Waldorf. Ainda de acordo com a entrevistada, todos aprendem a lidar com os medos que paralisam as ações do ser humano, a enfrentar as drogas modernas e o mundo confuso da modernidade, "um mundo cheio de nada". A inutilidade que ela vê no sistema escolar convencional se assemelha à crítica de Brandão na carta de um índio, chefe de uma tribo americana, que agradece aos brancos, mas diz que não enviará mais guerreiros a suas escolas porque, quando eles voltam, "eram maus corredores, ignorantes da vida da floresta e incapazes de suportar o frio e a fome. Não sabiam como caçar veado, construir uma cabana e falavam nossa língua muito mal" (2005, p. 8). A educação convencional era inútil: não servia para formar guerreiros nem conselheiros.

O estilo natural está impregnado da ideia de liberdade de expressão: mudar e ser o que quiser já é ter liberdade; optar por aquilo que não é convencional já é, de alguma forma, um modo de ser livre e natural. Poder mudar o gosto e escolher os alimentos representa uma ideia de liberdade que é também histórica na consolidação da classe média. Segundo Bourdieu, "a ideia de gosto, tipicamente burguesa, já que ela supõe a liberdade absoluta de escolha, é estreitamente associada à ideia de liberdade" (1979, p. 198). Um dos entrevistados relatou que, quando aderiu ao movimento de práticas alternativas, sabia fazer só farofa de ovos; então, a primeira atitude que tomou foi trocar os ovos pela banana; 
depois se inscreveu num curso de macrobiótica e foi se transformando num ótimo cozinheiro. Hoje, faz uma alimentação natural, não ingere carne e come queijos. Sente-se livre para escolher seus alimentos sem seguir doutrina alguma. Não é contra a carne, embora considere o abate de gado desvantajoso em termos ecológicos, porque acaba com as florestas.

A ideia de liberdade é contrária ao abate de animais. De acordo com Singer, o movimento da libertação animal é também o da libertação humana: contra todas as formas de tirania. Os animais são uma espécie de extensão do homem e devem ser tratados como semelhantes, não como criaturas descartáveis. Eles sentem dor e sofrem como nós. Segundo o autor, o vegetarianismo é uma forma prática e eficaz de acabar com todo esse sofrimento e a matança porque "ancora-se em uma base ainda mais sólida do que outros protestos e boicotes" (2004, p. 185), numa necessidade moral de se limpar de toda a maldade do homem.

O caráter descartável atribuído à vida dos animais reproduz a concepção de mercadoria. Nas palavras de Engels,

ao transformar todas as coisas em mercadorias, a produção capitalista destruiu todas as antigas relações tradicionais e substituiu os costumes herdados e os direitos históricos pela compra e venda, pelo 'livre' contrato. $\mathrm{O}$ jurisconsulto inglês $\mathrm{H}$. S. Maine acreditou ter feito um descobrimento extraordinário ao dizer que nosso progresso em relação às épocas anteriores consiste em que passamos from status to contract, isto é, de uma ordem de coisas herdada para outra livremente consentida; uma afirmação que, na medida em que é correta, já se encontrava de há muito no manifesto comunista (1964, pp. 65-6).

Se não comer carne é um valor positivo no campo do naturismo, no âmbito global a luta pela libertação animal muitas vezes 
é motivo de chacota e banaliza as denúncias que faz Singer (2004) sobre a criação e o abate de gado.

A alimentação natural continua com prestígio no espaço social globalizado, atualmente de modo associado à alimentação saudável. A Organização Mundial de Saúde (OMS) já incentivou o vegetarianismo como prática saudável da puberdade em diante, motivando o consumo de frutas e hortaliças. A indicação de alimentos in natura como opções saudáveis estimula a bricolagem no estilo natural.

No contexto atual, a luta por melhores condições de vida reafirma o estilo natural no incentivo à alimentação orgânica e familiar, tanto no sentido de combater a desigualdade social quanto no de segurança e qualidade gastronômica dos alimentos sem aditivos químicos. A valorização do natural, por um lado, motiva a agricultura familiar e orgânica - que promove um menor desgaste da terra e protege o planeta do estrago que pode levar a danos imprevisíveis - e, por outro, impulsiona uma democratização de mercado, com a entrada de produtores de pequeno e médio porte.

Assim, o estilo natural ganha prestígio como uma alimentação ecologicamente correta, que pode enfrentar a desigualdade social em sua disposição para a sustentabilidade do planeta. Esse estilo se constitui com o sentido de contracultura, de enfrentamento de um mal-estar social gerado por uma crise que, segundo Luz, "tem suas raízes não só nas condiçōes de trabalho do capitalismo globalizado, mas na própria transformação recente da cultura que é seu fruto" (2003, p. 42). 